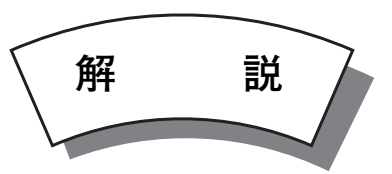

\title{
酸素空孔を有する強誘電性多結晶材料のフェーズフィールドシミュレーション
}

\section{Phase Field Simulation of Ferroelectric Polycrystals with Oxygen Vacancies}

\author{
成田史生*
}

Fumio NARITA

Key Words: Piezo-mesomechanics, Phase Field Method, Barium Titanate Ceramics, Ferroelectric Properties, Smart Materials and Structures

\section{1. はじめに}

近年、スマートフォンの高機能化やビックデータなど の活用により、高度情報化社会の進展が急速に進んでお り、あらゆるモノがインターネットに接続されるモノのイ ンターネット (Internet of Things：IoT) 時代を迎えようとし ている。一方、より高度で多数の情報を活用したサービス が展開されていくに伴い、センサ・情報端末の数は膨大と なり、それら電子・情報デバイスへの最適なエネルギー供 給が求められている。このため、自然界環境に広く存在す る未利用のエネルギー（振動、熱、光、電波など）を電気 エネルギーに変換する環境発電技術が注目され、例えば振 動発電を可能とするチタン酸ジルコン酸鉛 $(\mathrm{PZT})$ 系圧電材 料を用いて、至るところにある環境エネルギーを電子・情 報デバイス用電源として利用するための技術開発が進めら れている。しかしながら、PZT（現在、代替品がないため、 特定有害物質制限から除外されている）には有害物質（鉛） が含まれているため、環境問題上、非鉛系圧電材料の開発 が急務の課題となっている。

チタン酸バリウム $\left(\mathrm{BaTiO}_{3}\right)$ は、大きな誘電率と原料が安 価で安定供給が可能であるため、環境保全に対して PZT の 代替材料として期待されている ${ }^{1)}$ 。最近、 $\mathrm{BaTiO}_{3}$ 系セラミッ クスの誘電・圧電特性に及ぼす結晶粒径の影響が実験的に 検討され、誘電率および圧電定数は、結晶粒径の増大に伴 い増大し、粒径 $1 \mu \mathrm{m}$ 程度で極大值を示した後減少すると いう結果が報告されている ${ }^{2), 3)}$ 。また、 $\mathrm{BaTiO}_{3}$ 系セラミッ クスの誘電・圧電特性は、酸素分圧に依存するという報告 もある 4), 5)。高性能な $\mathrm{BaTiO}_{3}$ 系セラミックスを創成するた めには、最適な作製条件を見出すことが肝要であり、膨大 な数の実験を繰返す試行錯誤的な取り組みが行われている が、昨今、理論や数值シミュレーションなどによる物質探 索・材料開発が重要視されてきているようである。

最近、上辻ら ${ }^{\text {) }}$ は、結晶均質化法による強誘電性ヒステ リシス挙動のマルチスケール有限要素法の開発に成功し、
$\mathrm{BaTiO}_{3}$ 系セラミックスのヒステリシス・バタフライカー ブに及ぼす結晶配向分布の影響を解明している。一方、連 続体モデルに基づく材料組織形成過程の現象論的な数值シ ミュレーション法としてフェーズフィールド法が提唱さ れ ${ }^{7) 、}$ 、計算対象は、強誘電材料の分域・分極構造にも広がっ ている ${ }^{8)}$ 。強誘電性単結晶の分域・分極構造やヒステリシス・ バタフライカーブをフェーズフィールド法を用いて予測す る研究は数多く行われているが、多結晶材料を対象とした 研究は非常に少ない現状にある。

本稿では、 $\mathrm{BaTiO}_{3}$ 系強誘電性多結晶材料を対象に、材料. 構造設計のためのフェーズフィールド法の基礎的事項を取 り上げ、現在までの研究状況を展望する。また、誘電率お よび圧電定数の結晶粒径・酸素空孔（格子欠陥）密度依存 性について、数值シミュレーション結果を中心にその概略 を述べる。さらに、き裂進展シミュレーションにも言及する。

\section{2. フェーズフィールドモデル}

本章では、酸素空孔を有する $\mathrm{BaTiO}_{3}$ 系強誘電性多結晶材 料を取り上げ、フェーズフィールド法の概要について述べ る。系全体を対象とする直角座標系 O- $x_{1} x_{2} x_{3}$ (全体座標系) を考え、Choudhuryらの多結晶モデル 9)を基礎とし、また、 酸素空孔の影響は、Zhang らのモデル ${ }^{10)}$ に従って導入する。 さらに、両モデルにおけるエネルギー項などの関数形に違 いがある場合は、問題のない限り単純な方を採用する。

\section{1 分極ベクトルの発展方程式}

本節では、次の Time-Dependent Ginzburg-Landau 方程 式 ${ }^{11)}$ を数值解析し、分極ベクトルの成分 $P_{i}\left(x_{i}, t\right)(i=1,2,3)$ の時間発展を計算する数值シミュレーション法について概 説を行う。

$$
\frac{\partial P_{i}\left(x_{i}, t\right)}{\partial t}=-M \frac{\delta F}{\delta P_{i}\left(x_{i}, t\right)} \quad(i=1,2,3)
$$

上式中、 $F$ は強誘電性多結晶材料の自由エネルギー汎関数、

* 東北大学 大学院工学研究科 材料システム工学専攻（９ 980-8579 宮城県仙台市青葉区荒巻字青葉 6-6-02）

Department of Materials Processing, Graduate School of Engineering, Tohoku University (Aoba-yama 6-6-02, Sendai, Miyagi, 980-8579 Japan ) 
$M$ は分極の時間変化に対する易動度、 $t$ は時間である。式 (1) の自由エネルギーは、系の自由エネルギー密度 $f_{\text {all }}$ 体積 $V$ を用いて次式で与えられる。

$$
F=\int_{V} f_{\text {all }} d V=\int_{V}\left(f_{\text {bulk }}+f_{\text {grad }}+f_{\text {elas }}+f_{\text {elec }}\right) d V
$$

ここに、 $f_{\text {bulk }}$ は $f_{\text {all }}$ のバルク項、 $f_{\text {grad }}$ は勾配項、 $f_{\text {elas }}$ は弾性エ ネルギー項、 $f_{\text {elec }}$ は電気的エネルギー項である。

自由エネルギー密度のバルク項 $f_{\text {bulk }}$ は次のように表される。

$$
\begin{aligned}
f_{\text {bulk }}= & \alpha_{1}\left\{\left(P_{1}^{\mathrm{L}}\right)^{2}+\left(P_{2}^{\mathrm{L}}\right)^{2}+\left(P_{3}^{\mathrm{L}}\right)^{2}\right\} \\
& +\alpha_{11}\left\{\left(P_{1}^{\mathrm{L}}\right)^{4}+\left(P_{2}^{\mathrm{L}}\right)^{4}+\left(P_{3}^{\mathrm{L}}\right)^{4}\right\} \\
& +\alpha_{12}\left\{\left(P_{1}^{\mathrm{L}}\right)^{2}\left(P_{2}^{\mathrm{L}}\right)^{2}+\left(P_{2}^{\mathrm{L}}\right)^{2}\left(P_{3}^{\mathrm{L}}\right)^{2}\right. \\
& \left.+\left(P_{3}^{\mathrm{L}}\right)^{2}\left(P_{1}^{\mathrm{L}}\right)^{2}\right\} \\
& +\alpha_{111}\left\{\left(P_{1}^{\mathrm{L}}\right)^{6}+\left(P_{2}^{\mathrm{L}}\right)^{6}+\left(P_{3}^{\mathrm{L}}\right)^{6}\right\} \\
& +\alpha_{112}\left[\left(P_{1}^{\mathrm{L}}\right)^{2}\left\{\left(P_{2}^{\mathrm{L}}\right)^{4}+\left(P_{3}^{\mathrm{L}}\right)^{4}\right\}\right. \\
& +\left(P_{2}^{\mathrm{L}}\right)^{2}\left\{\left(P_{3}^{\mathrm{L}}\right)^{4}+\left(P_{1}^{\mathrm{L}}\right)^{4}\right\} \\
& \left.+\left(P_{3}^{\mathrm{L}}\right)^{2}\left\{\left(P_{1}^{\mathrm{L}}\right)^{4}+\left(P_{2}^{\mathrm{L}}\right)^{4}\right\}\right] \\
& +\alpha_{123}\left(P_{1}^{\mathrm{L}}\right)^{2}\left(P_{2}^{\mathrm{L}}\right)^{2}\left(P_{3}^{\mathrm{L}}\right)^{2} \\
& +\alpha_{1111}\left\{\left(P_{1}^{\mathrm{L}}\right)^{8}+\left(P_{2}^{\mathrm{L}}\right)^{8}+\left(P_{3}^{\mathrm{L}}\right)^{8}\right\} \\
& +\alpha_{1112}\left[\left(P_{1}^{\mathrm{L}}\right)^{6}\left\{\left(P_{2}^{\mathrm{L}}\right)^{2}+\left(P_{3}^{\mathrm{L}}\right)^{2}\right\}\right. \\
& +\left(P_{2}^{\mathrm{L}}\right)^{6}\left\{\left(P_{3}^{\mathrm{L}}\right)^{2}+\left(P_{1}^{\mathrm{L}}\right)^{2}\right\} \\
& \left.+\left(P_{3}^{\mathrm{L}}\right)^{6}\left\{\left(P_{1}^{\mathrm{L}}\right)^{2}+\left(P_{2}^{\mathrm{L}}\right)^{2}\right\}\right]
\end{aligned}
$$

ここに、上添え字 L は局所座標系（結晶粒の結晶方位に沿っ た座標系）での值を示している。Fig.1は、2 次元問題の 場合の全体座標系と局所座標系との関係を示したものであ る。局所座標系における分極べクトルの成分 $P_{i}^{\mathrm{L}}\left(x_{i}, t\right)(i=1,2$, 3) は、全体座標系における分極べクトルの成分 $P_{i}$ を用いて 次のように表される。

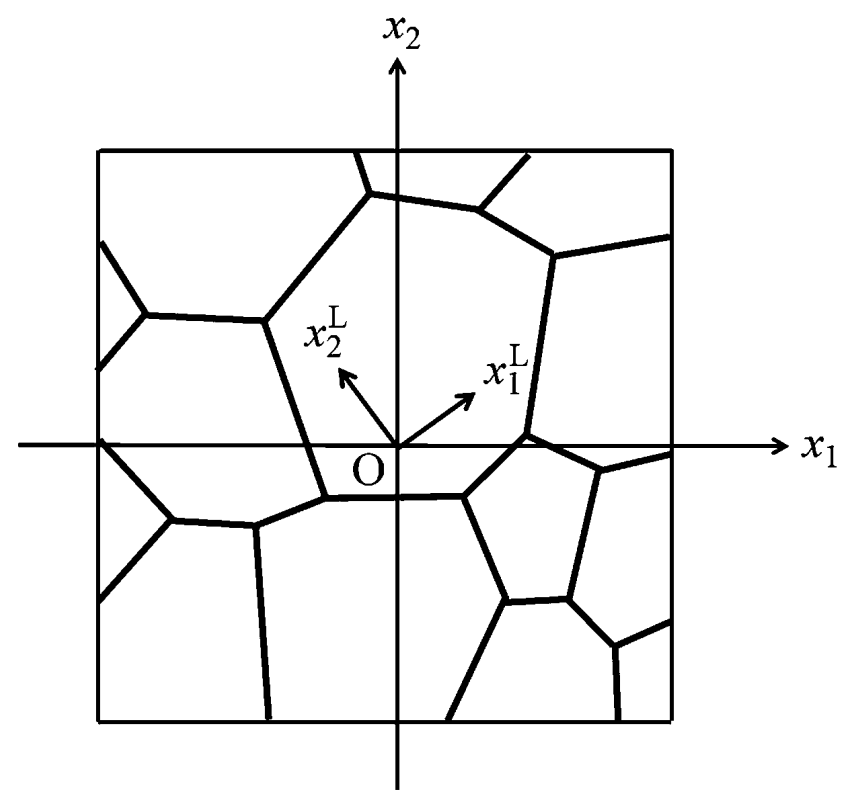

Fig.1 Global and local coordinates.

$$
\begin{aligned}
& P_{1}^{\mathrm{L}}=R_{11} P_{1}+R_{12} P_{2}+R_{13} P_{3} \\
& P_{2}{ }^{\mathrm{L}}=R_{21} P_{1}+R_{22} P_{2}+R_{23} P_{3} \\
& P_{3}^{\mathrm{L}}=R_{31} P_{1}+R_{32} P_{2}+R_{33} P_{3}
\end{aligned}
$$

ここに、 $R_{i j}(i, j=1,2,3)$ は、オイラー角 $(\theta, \varphi, \psi)$ を用いて 次のように与えられる。

$$
\begin{aligned}
& R_{11}=\cos \varphi \cos \psi-\cos \theta \sin \varphi \sin \psi \\
& R_{12}=\sin \varphi \cos \psi+\cos \theta \cos \varphi \sin \psi \\
& R_{13}=\sin \theta \sin \psi \\
& R_{21}=-\cos \varphi \sin \psi-\cos \theta \sin \varphi \cos \psi \\
& R_{22}=-\sin \varphi \sin \psi+\cos \theta \cos \varphi \cos \psi \\
& R_{23}=\sin \theta \cos \psi \\
& R_{31}=\sin \theta \sin \varphi \\
& R_{32}=-\sin \theta \cos \varphi \\
& R_{33}=\cos \theta
\end{aligned}
$$

$\mathrm{BaTiO}_{3}$ の場合、式 (3)における各係数は次のように与えら れる ${ }^{12)}$ 。

$$
\begin{array}{ll}
\alpha_{1}=4.124 \times(T-388) \times 10^{5} & \mathrm{~m}^{2} \mathrm{~N} / \mathrm{C}^{2} \\
\alpha_{11}=-20.97 \times 10^{7} & \mathrm{~m}^{6} \mathrm{~N} / \mathrm{C}^{4} \\
\alpha_{12}=79.74 \times 10^{7} & \mathrm{~m}^{6} \mathrm{~N} / \mathrm{C}^{4} \\
\alpha_{111}=129.4 \times 10^{7} & \mathrm{~m}^{10} \mathrm{~N} / \mathrm{C}^{6} \\
\alpha_{112}=-195.0 \times 10^{7} & \mathrm{~m}^{10} \mathrm{~N} / \mathrm{C}^{6} \\
\alpha_{123}=-250.0 \times 10^{7} & \mathrm{~m}^{10} \mathrm{~N} / \mathrm{C}^{6} \\
\alpha_{1111}=386.3 \times 10^{8} & \mathrm{~m}^{14} \mathrm{~N} / \mathrm{C}^{8} \\
\alpha_{1112}=252.9 \times 10^{8} & \mathrm{~m}^{14} \mathrm{~N} / \mathrm{C}^{8}
\end{array}
$$

ここに、Tは温度である。バルク項 $f_{\text {bulk }}$ は、温度に依存し て変化し、キュリー温度以下では特定の $P_{i}^{\mathrm{L}}(i=1,2,3)$ で極 小值をとるが、キュリー温度以上では $P_{i}^{\mathrm{L}}=0$ で極小となる。 すなわち、 $\mathrm{BaTiO}_{3}$ は、キュリー温度以下では自発分極が生 じて強誘電体となる（分極が存在した方がエネルギー的に 安定）が、キュリー温度以上では自発分極が消滅して常誘 電体となる。

式 (2)における自由エネルギー密度の勾配項 $f_{\text {grad }}$ は、分域 壁エネルギーを示し、方向依存性を無視すると次式のよう に近似的に表される ${ }^{9}$ 。

$$
\begin{aligned}
f_{\text {grad }}= & \frac{1}{2} G_{11}\left[\left\{\left(\frac{\partial P_{1}}{\partial x_{1}}\right)^{2}+\left(\frac{\partial P_{2}}{\partial x_{2}}\right)^{2}+\left(\frac{\partial P_{3}}{\partial x_{3}}\right)^{2}\right\}\right. \\
& +\left\{\left(\frac{\partial P_{1}}{\partial x_{2}}\right)^{2}+\left(\frac{\partial P_{2}}{\partial x_{1}}\right)^{2}\right\}+\left\{\left(\frac{\partial P_{2}}{\partial x_{3}}\right)^{2}+\left(\frac{\partial P_{3}}{\partial x_{2}}\right)^{2}\right\} \\
& +\left\{\left(\frac{\partial P_{3}}{\partial x_{1}}\right)^{2}+\left(\frac{\partial P_{1}}{\partial x_{3}}\right)^{2}\right\}
\end{aligned}
$$

ここに、 $G_{11}$ は、勾配エネルギー係数であり、 $\mathrm{BaTiO}_{3}$ の場合、 次のように与えられる ${ }^{10)}$ 。 


$$
\mathrm{G}_{11}=0.6 \times 10^{-7} \quad \mathrm{~m}^{4} \mathrm{~N} / \mathrm{C}^{2}
$$

式 (2) の弾性項 $f_{\text {elas }}$ は、負荷ひずみを考慮 ${ }^{13)}$ すると、次 式で与えられる。

$$
\begin{aligned}
f_{\text {elas }}= & \frac{1}{2} c_{11}\left\{\left(\varepsilon_{11}-\varepsilon_{11}^{\mathrm{s}}+\varepsilon_{11}^{0}\right)^{2}+\left(\varepsilon_{22}-\varepsilon_{22}^{\mathrm{s}}+\varepsilon_{22}^{0}\right)^{2}\right. \\
& \left.+\left(\varepsilon_{33}-\varepsilon_{33}^{\mathrm{s}}+\varepsilon_{33}^{0}\right)^{2}\right\} \\
+ & c_{12}\left\{\left(\varepsilon_{11}-\varepsilon_{11}^{\mathrm{s}}+\varepsilon_{11}^{0}\right)\left(\varepsilon_{22}-\varepsilon_{22}^{\mathrm{s}}+\varepsilon_{22}^{0}\right)\right. \\
& +\left(\varepsilon_{22}-\varepsilon_{22}^{\mathrm{s}}+\varepsilon_{22}^{0}\right)\left(\varepsilon_{33}-\varepsilon_{33}^{\mathrm{s}}+\varepsilon_{33}^{0}\right) \\
& \left.+\left(\varepsilon_{33}-\varepsilon_{33}^{\mathrm{s}}+\varepsilon_{33}^{0}\right)\left(\varepsilon_{11}-\varepsilon_{11}^{\mathrm{s}}+\varepsilon_{11}^{0}\right)\right\} \\
+ & c_{44}\left\{\left(\varepsilon_{12}-\varepsilon_{12}^{\mathrm{s}}+\varepsilon_{12}^{0}\right)^{2}+\left(\varepsilon_{23}-\varepsilon_{23}^{\mathrm{s}}+\varepsilon_{23}^{0}\right)^{2}\right. \\
& \left.+\left(\varepsilon_{31}-\varepsilon_{31}^{\mathrm{s}}+\varepsilon_{31}^{0}\right)^{2}\right\}
\end{aligned}
$$

ここに、 $\varepsilon_{i j}\left(x_{i}, t\right)(i, j=1,2,3)$ は全ひずみテンソルの成分、 $\varepsilon_{i j}^{\mathrm{s}}\left(x_{i}, t\right)$ は自発ひずみテンソルの成分、 $\varepsilon_{i j}{ }^{0}\left(x_{i}, t\right)$ は負荷ひず みテンソルの成分、 $c_{11}, c_{12}, c_{44}$ は弾性係数である。全ひず みテンソルの成分は、力の釣合い方程式（平衡方程式）に 基づき決定され 7),14)、Fourier 変換を用いて解くことができ る ${ }^{15)}$ 。一方、自発ひずみテンソルの成分は、局所座標系に おける自発ひずみテンソルの成分 $\varepsilon_{i j}^{\mathrm{sL}}\left(x_{i}, t\right)(i, j=1,2,3)$ を用 いて次のように表される。

$$
\begin{aligned}
\varepsilon_{11}^{\mathrm{s}}= & R_{11}^{2} \varepsilon_{11}^{\mathrm{sL}}+R_{21}^{2} \varepsilon_{22}^{\mathrm{sL}}+R_{31}^{2} \varepsilon_{33}^{\mathrm{sL}} \\
& +2\left(R_{21} R_{31} \varepsilon_{23}^{\mathrm{sL}}+R_{31} R_{11} \varepsilon_{31}^{\mathrm{sL}}+R_{11} R_{21} \varepsilon_{12}^{\mathrm{sL}}\right) \\
\varepsilon_{22}^{\mathrm{s}}= & R_{12}^{2} \varepsilon_{11}^{\mathrm{sL}}+R_{22}^{2} \varepsilon_{22}^{\mathrm{sL}}+R_{32}^{2} \varepsilon_{33}^{\mathrm{sL}} \\
& +2\left(R_{22} R_{32} \varepsilon_{23}^{\mathrm{sL}}+R_{32} R_{12} \varepsilon_{31}^{\mathrm{sL}}+R_{12} R_{22} \varepsilon_{12}^{\mathrm{sL}}\right) \\
\varepsilon_{33}^{\mathrm{s}}= & R_{13}^{2} \varepsilon_{11}^{\mathrm{sL}}+R_{23}^{2} \varepsilon_{22}^{\mathrm{sL}}+R_{33}^{2} \varepsilon_{33}^{\mathrm{sL}} \\
& +2\left(R_{23} R_{33} \varepsilon_{23}^{\mathrm{sL}}+R_{33} R_{13} \varepsilon_{31}^{\mathrm{sL}}+R_{13} R_{23} \varepsilon_{12}^{\mathrm{sL}}\right) \\
\varepsilon_{23}^{\mathrm{s}}= & R_{12} R_{13} \varepsilon_{11}^{\mathrm{sL}}+R_{22} R_{23} \varepsilon_{22}^{\mathrm{sL}}+R_{32} R_{33} \varepsilon_{33}^{\mathrm{sL}} \\
& +\left(R_{23} R_{33}+R_{32} R_{23}\right) \varepsilon_{23}^{\mathrm{sL}}+\left(R_{32} R_{13}+R_{12} R_{33}\right) \varepsilon_{31}^{\mathrm{sL}} \\
& +\left(R_{12} R_{23}+R_{22} R_{13}\right) \varepsilon_{12}^{\mathrm{sL}} \\
\varepsilon_{31}^{\mathrm{s}}= & R_{13} R_{11} \varepsilon_{11}^{\mathrm{sL}}+R_{23} R_{21} \varepsilon_{22}^{\mathrm{sL}}+R_{33} R_{31} \varepsilon_{33}^{\mathrm{sL}} \\
& +\left(R_{23} R_{31}+R_{33} R_{21}\right) \varepsilon_{23}^{\mathrm{sL}}+\left(R_{33} R_{11}+R_{13} R_{31}\right) \varepsilon_{31}^{\mathrm{sL}} \\
& +\left(R_{13} R_{21}+R_{23} R_{11}\right) \varepsilon_{12}^{\mathrm{sL}} \\
\varepsilon_{12}^{\mathrm{s}}= & R_{11} R_{12} \varepsilon_{11}^{\mathrm{sL}}+R_{21} R_{22} \varepsilon_{22}^{\mathrm{sL}}+R_{31} R_{32} \varepsilon_{33}^{\mathrm{sL}} \\
& +\left(R_{21} R_{32}+R_{31} R_{22}\right) \varepsilon_{23}^{\mathrm{sL}}+\left(R_{31} R_{12}+R_{11} R_{32}\right) \varepsilon_{31}^{\mathrm{sL}} \\
& +\left(R_{11} R_{22}+R_{21} R_{12}\right) \varepsilon_{12}^{\mathrm{sL}} \\
&
\end{aligned}
$$

また、式（8）の局所座標系における自発ひずみテンソルの 成分は、自発分極ベクトルの成分 $P_{i}^{\mathrm{L}}\left(x_{i}, t\right)(i=1,2,3)$ を用 いて次式のように与えられる。

$$
\begin{aligned}
& \varepsilon_{11}^{\mathrm{sL}}=Q_{11}\left(P_{1}^{\mathrm{L}}\right)^{2}+Q_{12}\left\{\left(P_{2}^{\mathrm{L}}\right)^{2}+\left(P_{3}^{\mathrm{L}}\right)^{2}\right\} \\
& \varepsilon_{22}^{\mathrm{sL}}=Q_{11}\left(P_{2}{ }^{\mathrm{L}}\right)^{2}+Q_{12}\left\{\left(P_{3}^{\mathrm{L}}\right)^{2}+\left(P_{1}^{\mathrm{L}}\right)^{2}\right\} \\
& \varepsilon_{33}^{\mathrm{sL}}=Q_{11}\left(P_{3}^{\mathrm{L}}\right)^{2}+Q_{12}\left\{\left(P_{1}^{\mathrm{L}}\right)^{2}+\left(P_{2}^{\mathrm{L}}\right)^{2}\right\} \\
& \varepsilon_{12}^{\mathrm{sL}}=Q_{44} P_{1}{ }^{\mathrm{L}} P_{2}^{\mathrm{L}} \\
& \varepsilon_{23}^{\mathrm{sL}}=Q_{44} P_{2}{ }^{\mathrm{L}} P_{3}^{\mathrm{L}} \\
& \varepsilon_{31}^{\mathrm{sL}}=Q_{44} P_{3}{ }^{\mathrm{L}} P_{1}^{\mathrm{L}}
\end{aligned}
$$

ここに、 $Q_{11}, Q_{12}, Q_{44}$ は電歪係数である。 $\mathrm{BaTiO}_{3}$ の弾性係
数および電歪係数は、Wang et al ${ }^{16)}$ の第一原理計算により、 次のように得られている。

$$
\begin{aligned}
c_{11} & =300 \quad \mathrm{GPa} \\
c_{12} & =109 \quad \mathrm{GPa} \\
c_{44} & =124 \quad \mathrm{GPa} \\
Q_{11} & =0.115 \quad \mathrm{~m}^{2} / \mathrm{C} \\
Q_{12} & =-0.033 \quad \mathrm{~m}^{2} / \mathrm{C} \\
Q_{44} & =0.041 \mathrm{~m}^{2} / \mathrm{C}
\end{aligned}
$$

式(2)の電気的エネルギー項 $f_{\text {elec }}$ は次のように与えられる。

$$
f_{\text {elec }}=-\frac{1}{2}\left(E_{1} P_{1}+E_{2} P_{2}+E_{3} P_{3}\right)+f_{\text {appl }}+f_{\text {defect }}
$$

ここに、 $E_{i}\left(x_{i}, t\right)=-\partial \phi\left(x_{i}, t\right) / \partial x_{i}(i=1,2,3)$ は電場の強さべク トルの成分であり、静電ポテンシャル $\phi$ は無電荷の Gauss の方程式に基づき決定される。また、 $f_{\text {appl }}$ は負荷電場 $E_{i}^{0}\left(x_{i}, t\right)$ $(i=1,2,3)$ によって生じる電気的エネルギー、 $f_{\text {defect }}$ は酸素 空孔の存在によって生じる電気的エネルギーである。負荷 電場によって生じる電気的エネルギーは次にように表され る。

$$
f_{\text {appl }}=-\left(E_{1}^{0} P_{1}+E_{2}^{0} P_{2}+E_{3}^{0} P_{3}\right)
$$

また、酸素空孔によって生じる電気的エネルギーは次式で 与えられる。

$$
f_{\text {defect }}=-\frac{1}{2}\left(E_{1}^{\text {defect }} P_{1}+E_{2}^{\text {defect }} P_{2}+E_{3}^{\text {defect }} P_{3}\right)
$$

ここに、 $E_{i}^{\text {defect }}\left(x_{i}, t\right)(i=1,2,3)$ は、酸素空孔によって生じる 電場の強さべクトルの成分で、一つの空孔によって誘起さ れる局所分極の大きさ $P^{\text {defect }}=0.515 \mathrm{C} / \mathrm{m}^{2}$ を用いて次のよう に得られる ${ }^{10)}$ 。

$$
E_{i}^{\text {defect }}=\frac{1.02}{\pi \epsilon_{0}} N_{\mathrm{d}} V_{0} P^{\text {defect }} \frac{P_{i}}{\left|P_{i}\right|}(\mathrm{i}=1,2,3)
$$

上式中、 $\epsilon_{0}=8.85 \times 10^{-12} \mathrm{~F} / \mathrm{m}$ は自由空間の誘電率、 $N_{\mathrm{d}}\left(x_{i}, t\right)$ $(i=1,2,3)$ は酸素空孔の数密度、 $V_{0}=64.3195479104 \AA^{3}$ は単 位胞の体積である。

\section{2 酸素空孔密度の発展方程式}

$\mathrm{BaTiO}_{3}$ 系単結晶の分域構造に及ぼす点欠陥の影響につい

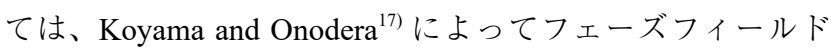
解析が実施され、検討されている。本節では、Zhang ら ${ }^{10)}$ によって提案された酸素空孔密度の発展方程式について紹 介する。式 (13)における酸素空孔密度 $N_{\mathrm{d}}$ は、次の拡散方 程式に支配される ${ }^{18)}$ 。

$$
\begin{array}{r}
\frac{\partial N_{\mathrm{d}}\left(x_{i}, t\right)}{\partial t}=\nabla \cdot\left[\beta_{\mathrm{d}} N_{\mathrm{d}}\left(x_{i}, t\right) \nabla\left(\frac{\partial W_{\mathrm{d}}}{\partial N_{\mathrm{d}}\left(x_{i}, t\right)}+e Z \phi\left(x_{i}, t\right)\right)\right] \\
(i=1,2,3)
\end{array}
$$


ここに、 $\beta_{\mathrm{d}}=5 \times 10^{5} \mathrm{~m}^{2} / \mathrm{sJ}$ は酸素空孔の易動度、 $W_{\mathrm{d}}$ は酸 素空孔によるへルムホルッの自由エネルギー密度、 $e=$ $1.6021773 \times 10^{-19} \mathrm{C}$ は電気素量、 $Z$ は酸素空孔の有効価電子 数である。式(14)の $\partial W_{\mathrm{d}} / \partial N_{\mathrm{d}}$ は、原子数を変えずに酸素空 孔のみを単位体積中に 1 個増やしたときのへルムホルッの 自由エネルギー密度変化量を表している。ここでは、酸素 空孔が非常に少ない場合を考え、自由エネルギー密度の変 化量 $\partial W_{\mathrm{d}} / \partial N_{\mathrm{d}}$ を空孔の部分モル自由エネルギー（化学ポテ ンシャル） $\mu_{\mathrm{d}}$ で近似できるとし、次のように仮定する。

$$
\frac{\partial W_{\mathrm{d}}}{\partial N_{\mathrm{d}}}=\frac{\mu_{\mathrm{d}}}{N_{\mathrm{A}}}
$$

上式中、 $\mu_{\mathrm{d}}$ は単位物質量当たりの自由エネルギーであるた め、右辺はアボガドロ数 $N_{\mathrm{A}}=6.0221 \times 10^{-23} 1 / \mathrm{mol}$ で割られ ている。また、牒は次のように与えられる。

$$
\mu_{\mathrm{d}}=G_{\mathrm{d}}+N_{\mathrm{A}} Z \varepsilon\left(1-X_{\mathrm{d}}\right)^{2}+N_{\mathrm{A}} k_{\mathrm{B}} T \ln X_{\mathrm{d}}
$$

ここに、 $G_{\mathrm{d}}$ は酸素空孔におけるギブスの自由エネルギー、 $\varepsilon$ は「原子・酸素空孔の結合エネルギー」と「原子同士の 結合エネルギーと酸素空孔同士の結合エネルギーの平均 值」との差、 $X_{\mathrm{d}}$ は酸素空孔のモル分率、 $k_{\mathrm{B}}=1.3807 \times 10^{-23} \mathrm{~J} /$ $\mathrm{K}$ はボルッマン定数である。式(15) を式(14) に代入し、式 (16) を考慮すると、次式が得られる。

$$
\begin{array}{r}
\frac{\partial N_{\mathrm{d}}\left(x_{i}, t\right)}{\partial t}=\nabla \cdot\left\{D \nabla N_{\mathrm{d}}\left(x_{i}, t\right)+\beta_{\mathrm{d}} e Z N_{\mathrm{d}}\left(x_{i}, t\right) \nabla \phi\left(x_{i}, t\right)\right\} \\
(i=1,2,3)
\end{array}
$$

ここに

$$
D=\beta_{\mathrm{d}} k_{\mathrm{B}} T\left\{1-\frac{2 Z \varepsilon\left(1-X_{\mathrm{d}}\right) X_{\mathrm{d}}}{k_{\mathrm{B}} T}\right\}
$$

酸素空孔が非常に少ない場合 $\left(X_{\mathrm{d}} \ll 1\right) 、 \mathrm{D} \simeq \beta_{\mathrm{d}} k_{\mathrm{B}} T$ と近似で き、酸素空孔密度の発展方程式 (17) は次のように表される。

$$
\frac{\partial N_{\mathrm{d}}\left(x_{i}, t\right)}{\partial t}=\nabla \cdot\left\{\beta_{\mathrm{d}} k_{\mathrm{B}} T \nabla N_{\mathrm{d}}\left(x_{i}, t\right)+\beta_{\mathrm{d}} e Z N_{\mathrm{d}}\left(x_{i}, t\right) \nabla \phi\left(x_{i}, t\right)\right\}
$$

酸素空孔の価電子数は、 2 上り小さく、ここでは $Z=1$ と仮 定する。式 (19) は静電ポテンシャル $\phi$ と温度 $T$ に依存する。

\section{3 多結晶粒成長の発展方程式}

最近、Wang et al. ${ }^{19)}$ は、7 個の正六角形結晶粒からなる強 誘電性多結晶材料をモデル化し、フェーズフィールド解析 を行って、非線形挙動に及ぼす分域構造の影響を明らかに

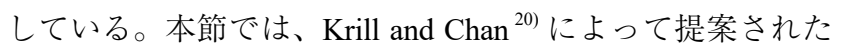
多結晶粒成長のフェーズフィールドモデルについて概説す る。多結晶材料の粒成長を記述するため、位置 $x_{i}(i=1,2,3)$ 、 時間 $t$ において異なる結晶方位を有する領域の存在位置を 表す秩序変数 $\chi_{q}\left(x_{i}, t\right)(q=1, \cdots, Q)$ を導入する。下添字 $q$ は 方位の異なる結晶粒を表す整理番号で、 $Q$ は結晶粒の数で
ある。多結晶粒成長の発展方程式は、次のように与えられる。

$$
\frac{\partial \chi_{q}\left(x_{i}, t\right)}{\partial t}=-M_{q} \frac{\delta F}{\delta \chi_{q}\left(x_{i}, t\right)} \quad(i=1,2,3)
$$

ここに、 $M_{q}(q=1, \cdots, Q)$ は緩和運動係数であり、ここでは $M_{q}=1 \mu \mathrm{m}^{3} / \mathrm{Js}(q=1, \cdots, Q)$ と仮定する。また、式(20)に㧈 ける自由エネルギー沉関数は次式で表される。

$$
\begin{aligned}
F= & \int_{V}\left\{-\frac{1}{2} \sum_{q=1}^{Q} \chi_{q}^{2}+\frac{1}{4} \sum_{q=1}^{Q} \chi_{q}^{4}+\frac{1}{2} \sum_{q=1}^{Q} \sum_{s>q}^{Q} \chi_{q}^{2} \chi_{s}^{2}\right. \\
& \left.+\sum_{q=1}^{Q}\left(\nabla \chi_{q}\right)^{2}\right\} d V
\end{aligned}
$$

\section{3. 電気力学的挙動解析}

本章では、酸素空孔を有する $\mathrm{BaTiO}_{3}$ 系強誘電性多結晶材 料の誘電率㧍よび圧電定数に注目した数值シミュレーショ ン結果について述べる。解析は、直角座標系 O- $x_{1} x_{3}$ に扮け る $3.3 \times 3.3 \mu \mathrm{m}$ の分極 $\mathrm{BaTiO}_{3}{ }^{21}$ を対象に、周期境界条件を 用いて行われ、平面ひずみが仮定されている。また、温度 は $T=300 \mathrm{~K}$ 、負荷ひずみは $\varepsilon_{i j}^{0}(i, j=1,2,3)=0$ である。

Fig.2 は、分極 $P_{3}$ と負荷電場 $E_{3}{ }^{0}$ との関倸を示したもの

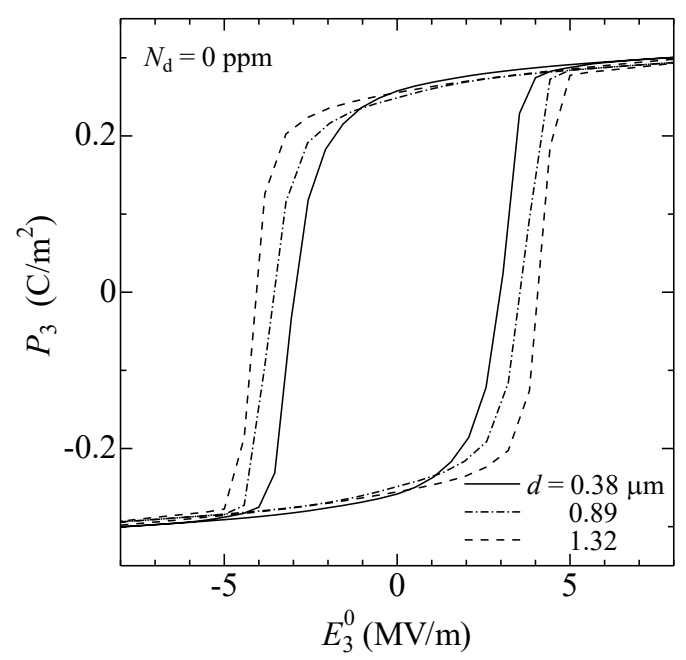

Fig.2 Polarization versus electric field $\left(N_{\mathrm{d}}=0 \mathrm{ppm}\right)$.

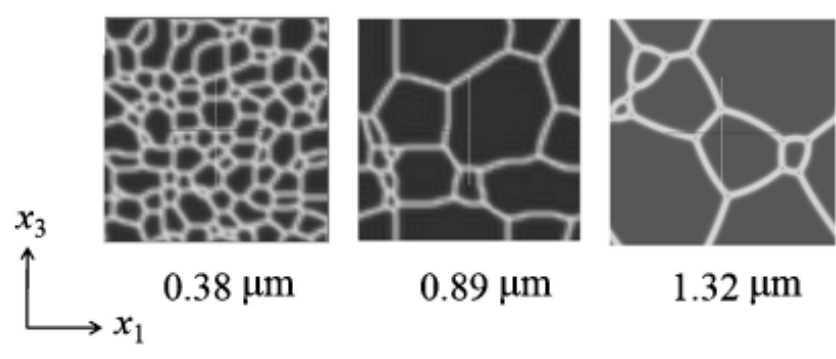

Fig.3 Gran structures generated using the phase field model for grain growth. 


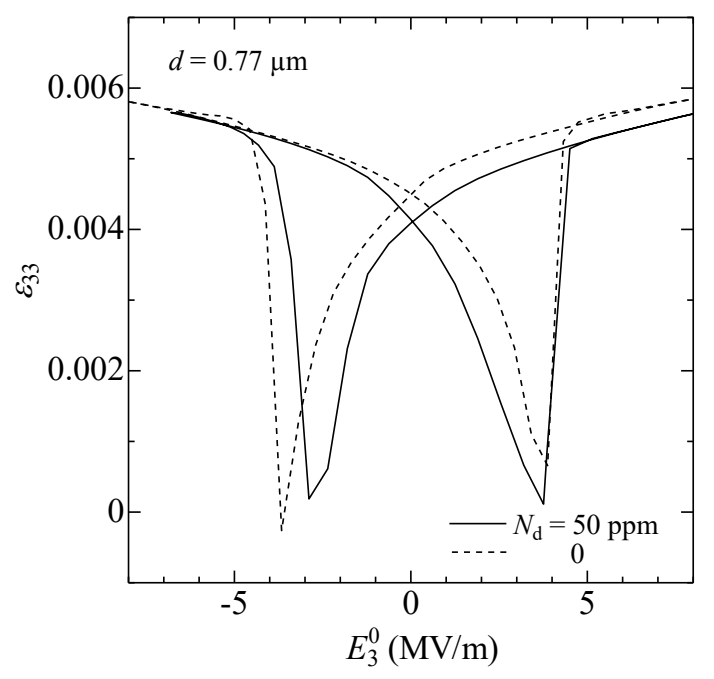

Fig.4 Normal strain versus electric field $\left(N_{\mathrm{d}}=0 \mathrm{ppm}\right)$.

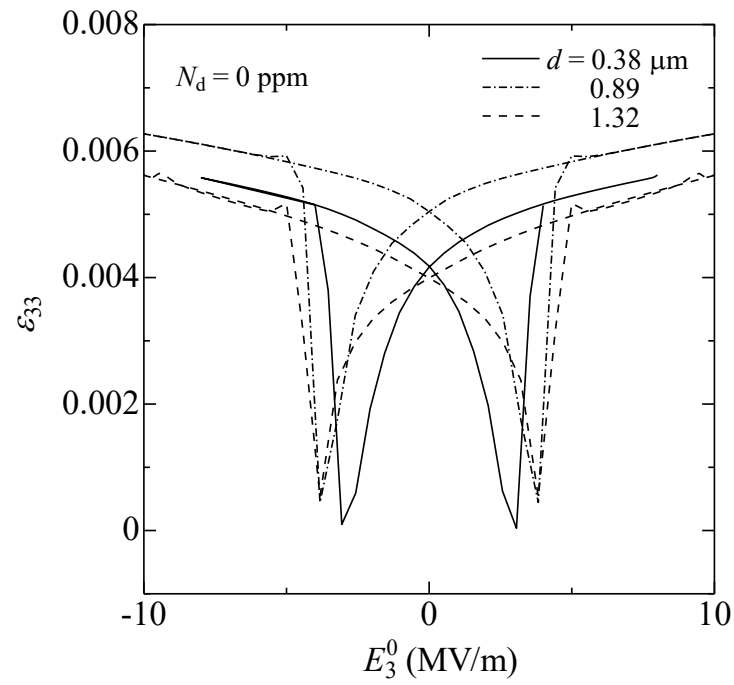

Fig.5 Normal strain versus electric field $\left(N_{\mathrm{d}}=0,50 \mathrm{ppm}\right)$.

で、平均結晶粒径 $d=0.38,0.89,1.32 \mu \mathrm{m}$ (Fig.3）の場合で あり、酸素空孔密度は $N_{\mathrm{d}}=0 \mathrm{ppm}$ と仮定している。Fig.4 は、ひずみ $\varepsilon_{33}$ を示した Fig.2 と同様の結果である。 $\mathrm{BaTiO}_{3}$ 系多結晶のヒステリシスカーブ (分極と負荷電場との関係) およびバタフライカーブ（ひずみと負荷電場との関係）は 結晶粒径に依存して変化した。また、結果は示していない が、同様に応力ーひずみ曲線も予測することが可能である。 Fig.5 は、ひずみ $\varepsilon_{33}$ と負荷電場 $E_{3}{ }^{0}$ との関係を示したもので、 平均結晶粒径 $d=0.77 \mu \mathrm{m}$ 、酸素空孔密度 $N_{\mathrm{d}}=0,50 \mathrm{ppm}$ の 場合である。

Table 1 は、誘電率に及ぼす酸素空孔密度の影響を示し たもので、平均結晶粒径 $d=0.77 \mu \mathrm{m}$ の場合である。誘電 率は、酸素空孔密度の増大に伴い増大し、500 ppm 付近で
Table 1 Permittivity of polycrystals with various oxygen vacancy densities $(d=0.77 \mu \mathrm{m})$.

\begin{tabular}{|l|c|c|c|c|}
\hline$N_{\mathrm{d}}(\mathrm{ppm})$ & 0 & 100 & 500 & 1000 \\
\hline$\epsilon_{33}\left(\times 10^{-10} \mathrm{C} / \mathrm{Vm}\right)$ & 162 & 176 & 183 & 108 \\
\hline
\end{tabular}

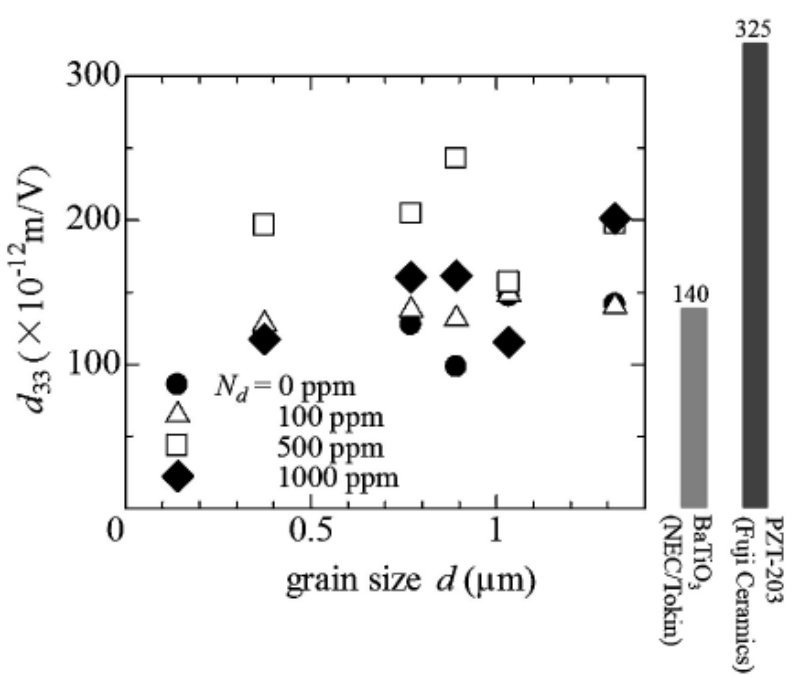

Fig.6 Piezoelectric coefficient versus average grain radius.

極大值を示した後減少した。Fig.6は、圧電定数と平均結 晶粒径との関係を示したもので、酸素空孔密度 $N_{\mathrm{d}}=0,100$, $500,1000 \mathrm{ppm}$ の場合である。比較のため、NEC/Tokin 製の $\mathrm{BaTiO}_{3}$ 系セラミックス、富士セラミックス製の PZT-203の 值 ${ }^{22)}$ も示している。圧電定数は、結晶粒径の増大に伴い 増大し、極大值を示して減少した。また、極大值を示す結 晶粒径の值は酸素空孔密度に依存している。最適な結晶粒 径（熱処理温度・時間に依存）や格子欠陥密度（添加元素 に依存）を見出すことで、市販の PZT を超える圧電定数の $\mathrm{BaTiO}_{3}$ 系強誘電性多結晶材料を作製することが可能とな る。

\section{4. き裂進展解析の現状}

強誘電性多結晶セラミックスは、機能材料として注目を 集めているが、材料の脆性や使用中の破壊が問題となっ ている。また、強誘電材料の破壞・疲労挙動に関する理論 的・実験的研究が行われているが、き裂進展の結晶粒・分 域構造依存性については研究例も少なく、詳細な検討が必 要である。特に、圧電セラミックス中に存在するき裂は、 分極方向に垂直に進展しやすく、破壊形態は、負荷電場の 正負や大きさによって粒内・粒界破壊と変化する傾向にあ り 23)-25)、結晶粒径の大きさにも依存するようである。本章 では、フェーズフィールド法による $\mathrm{BaTiO}_{3}$ 系強誘電性多結 晶材料のき裂進展解析の現状について紹介する。 

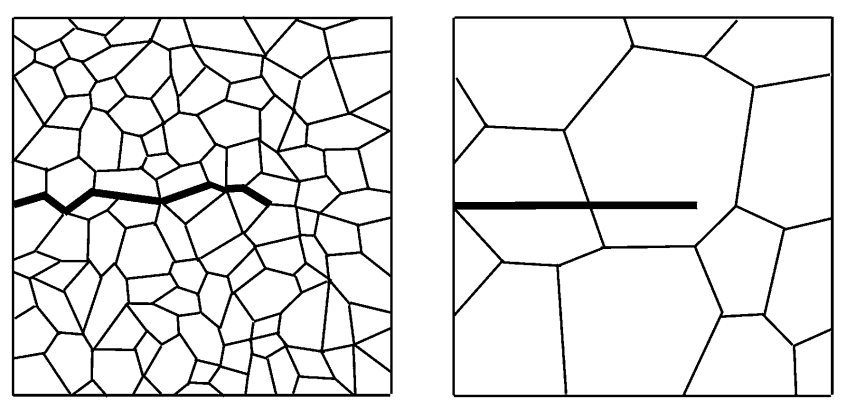

Fig.7 Crack path in polycrystals.

き裂を有する $\mathrm{BaTiO}_{3}$ 系強誘電性多結晶材料のフェーズ フィールドシミュレーションは、Abdollahi and Arias ${ }^{20)} に$ よって行われており、き裂進展経路の結晶粒径依存性やき 裂進展による分域構造変化について検討されている。また、 Fig.7に示すように、微粒 $\mathrm{BaTiO}_{3}$ 中に存在するき裂は、偏 向が認められ、粒界に沿って進展するが、粗粒 $\mathrm{BaTiO}_{3}$ 中 に存在するき裂は粒内を進展するという結果が得られてい る。今後は、酸素空孔やき裂を有する $\mathrm{BaTiO}_{3}$ 系強誘電性多 結晶材料の電場下に扔ける挙動の解明が望まれる。

\section{5. おわりに}

本稿では、酸素空孔を有する $\mathrm{BaTiO}_{3}$ 系強誘電性多結晶材 料に注目し、電気力学的挙動のフェーズフィールドシミュ レーションに関する現在までの研究状況について展望し た。また、き裂進展シミュレーションの現状についても紹 介した。今後、電子デバイスから鉛を排除する動きが活発 化し、 $\mathrm{BaTiO}_{3}$ 系強誘電性多結晶材料の開発がますます進む ことが予想され、フェーズフィールドシミュレーションに 基づく材料・構造最適化研究のさらなる発展が望まれる。

\section{謝 辞}

数值計算にご協力いただいた材料システム設計学分野修 士学生の小林拓矢氏に感謝の意を表します。

\section{参考文献}

1) 日本 AEM 学会: “無鉛圧電セラミックス・デバイス”、養賢堂、 (2008) 31-43.

2) P. Zheng, J. L. Zhang, Y. Q. Tan, and C. L. Wang: Acta Mater., 60 (2012) 5022-5030.
3) Y. Huan, X. Wang, J. Fang and L. Li: J. Eur. Ceram. Soc., 34 (2014) 1445-1448.

4) Q. Feng, C. J. McConville, D. D. Edwards, D. E. McCauley and M. Chu: J. Am. Ceram. Soc., 89 (2006) 894-901.

5) H. T. Langhammer, D. Makovec, Y. Pu, H.-P. Abicht and M. Drofenik: J. Eur. Ceram. Soc., 26 (2006) 2899-2907.

6) Y. Uetsuji, T. Hata, T. Oka, H. Kuramae and K. Tsuchiya: Comput. Mater. Sci., 106 (2015) 100-110.

7) 小山敏幸: “材料設計計算工学 計算組織学偏 フェーズフィー ルド法による組織形成解析”、内田老鶴戋、(2011).

8) Y. Su and G. J. Weng:"Handbook of Micromechanics and Nanomechanics”, ed. by S. Li and X.-L. Gao, Pan Stanford Publishing Ptd. Ltd., 2013, p73.

9) S. Choudhury, Y. L. Li, C. Krill III and L. Q. Chen: Acta Mater., 55 (2007) 1415-1426.

10) Y. Zhang, J. Li and D. Fang: Physical Review B 82 (2010) 064103.

11) J. W. Cahn and J. E. Hilliard: J. Chem. Phys. 28 (1958) 258-267.

12) Y. L. Li, L. E. Cross and L. Q. Chen: J. Appl. Phys. 98 (2005) 064101.

13) J. Wang, Y. Li, L.-Q. Chen and T.-Y. Zhang: Acta Mater. 53 (2005) 2495-2507.

14) A. G. Khachaturyan : "Theory of Structural Transformations in Solids", Wiley and Sons, (1983).

15) T. Mura : "Micromechanics of Defects in Solids", Martinus Nijhoff, (1982).

16) J. J. Wang, F. Y. Meng, X. Q. Ma, M. X. Xu and L. Q. Chen: J. Appl. Phys. 108 (2010) 034107

17) T. Koyama and H. Onodera: Materials Transactions 50 (2009) 970976.

18) Y. Xiao and K. Bhattacharya: Arch. Ration. Mech. Anal. 189 (2008) 59-95.

19) J. Wang, W. Su, T. Shimada, T. Kitamura and T.-Y. Zhang,: Acta Mater. 61 (2013) 6037-6049.

20) C. E. Krill III and E. C. Chen: Acta Mater. 50 (2002) 3057-3073.

21) Y. Shindo, F. Narita and T. Kobayashi: J. Appl. Phys. 117 (2015) 234103.

22) F. Narita and Y. Shindo: Int. J. Metal. Mater. Eng., in press.

23) F. Narita, Y. Shindo and F. Saito, J. Am. Ceram. Soc. 90 (2007) 2517-2524.

24) F. Narita, Y. Morikawa, Y. Shindo and M. Sato, J. Euro. Ceram. Soc. 32 (2012) 3759-3766.

25) F. Narita, Y. Shindo and M. Sato, JSME J. Solid Mech. Mater. Eng. 7 (2013) 530-539.

26) A. Abdollahi and I. Arias: Int. J. Fract. 174 (2012) 3-15. 